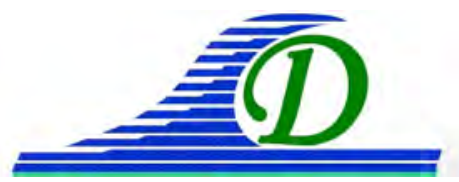

XIII ${ }^{\text {èmes }}$ Journées Nationales Génie Côtier - Génie Civil Dunkerque, 2-4 juillet 2014

DOI:10.5150/jngcgc.2014.042 (C) Editions Paralia CFL disponible en ligne - http://www.paralia.fr - available online

\title{
Impact de l'évolution récente du littoral sur les infrastructures portuaires : cas du golfe de Gabès, SE Tunisien
}

\author{
Maher GZAM, Adel KHARROUBI, Younes JEDOUI
}

1. U.R : Hydrosciences Appliquées, Institut Supérieur des Sciences et Techniques des Eaux, Université de Gabès, Tunisie.gzammaher79@gmail.com ; adel.kharroubi@isstegb.rnu.tn ; jedoui.younes@isstegb.rnu.tn

\section{Communication non présentée}

\section{Résumé :}

L’évolution récente (depuis les années 1980) du littoral du golfe de Gabès montre une tendance vers la progradation. Cette évolution hydrosédimentaire est perturbée par des aménagements portuaires. Le déséquilibre sédimentaire se traduit par l'ensablement des ouvrages portuaires à l'image des ports de pêche de Gabès et d'Aghir. Le risque d'un arrêt total d'exploitation de ces ouvrages, à l'image du port de pêche d'Aghir, est inévitable dans le cas où la solution envisagée ne tiendrait pas compte des caractéristiques géo-morpho-dynamiques du littoral. Le courant de dérive littorale, constituant le facteur majeur du transit sédimentaire, est à l'origine du comblement de ces ouvrages. L'analyse de la variation de la pente le long du profil transversal du littoral de Gabès montre une section de transition hydrodynamique ayant un faible transit sédimentaire. Cette section bathymétrique constitue un site potentiel d'implantation du port.

Mots clés : Accrétion, Ensablement, Port de pêche, Rupture de pente, Golfe de Gabès. 
Thème 2 - Dynamique sédimentaire 
XIII ${ }^{\text {èmes }}$ Journées Nationales Génie Côtier - Génie Civil Dunkerque, 2-4 juillet 2014 
Thème 2 - Dynamique sédimentaire 
XIII ${ }^{\text {èmes }}$ Journées Nationales Génie Côtier - Génie Civil Dunkerque, 2-4 juillet 2014 
Thème 2 - Dynamique sédimentaire 
XIII ${ }^{\text {èmes }}$ Journées Nationales Génie Côtier - Génie Civil Dunkerque, 2-4 juillet 2014 
Thème 2 - Dynamique sédimentaire 
XIII ${ }^{\text {èmes }}$ Journées Nationales Génie Côtier - Génie Civil Dunkerque, 2-4 juillet 2014 
Thème 2 - Dynamique sédimentaire 